\title{
Nova Farmacotécnica para Velhos Agentes
}

A Anestesiologia Experimental é uma área que pode abrir hovos caminhos e propor soluções para problemas enfrentados na Anestesiologia Clínica.

Em 1995, Eger e MacLoad estudaram a administração por via venosa de uma emulsão de isoflurano em camundongos ${ }^{1}$. As principais vantagens relacionadas pelos autores foram eliminação do circuito anestésico do respirador e da capacidade residual funcional do pulmão, permitindo uma aceleração da indução da anestesia. Ao final do estudo os autores concluíram que a técnica foi possível, a indução e manutenção da anestesia desenvolveram-se de maneira segura e reprodutível. Sugeriram também que outros estudos com animais maiores seriam importantes para determinar as características, toxicológicas, físico-químicas, farmacocinéticas e farmacodinâmicas desta mistura ou de outras similares.

Em 1984 e 1999, um grupo europeu e um americano, estudaram respectivamente os efeitos farmacocinéticos e farmacodinâmicos de emulsão lipídica de halotano em cães, ratos e porcos. Estes trabalhos descrevem grupos com injeção única e infusão, isoladas ou combinadas, com comportamento farmacológico semelhante à administração por via inalatória. Não foi observado efeito tóxico, mas registrado um aumento de 12 vezes na concentração plasmática de triglicérides no grupo de cães ${ }^{2-4}$.

Neste número da Revista Brasileira de Anestesiologia, um grupo de pesquisadores brasileiros ${ }^{5}$ apresentou um modelo experimental em porcos, para estudar algumas das características farmacocinéticas e farmacodinâmicas de emulsão de isoflurano. Os resultados obtidos são similares aos de Eger e MacLoad, com uma relação direta entre os efeitos farmacodinâmicos e a concentração expirada de isoflurano. Em nosso meio a indução da anestesia, por via inalatória, é empregada principalmente em crianças, quando nem sempre é fácil a obtenção de um acesso venoso. Pelas características fisiológicas da função pulmonar deste grupo de pacientes, normalmente a indução por via inalatória é rápida. A eventual vantagem obtida no tempo de indução com o uso da via venosa, contrapõe-se à dificuldade de seu acesso.

Considerando a contaminação do ambiente pelo uso de agentes anestésicos por via inalatória, o seu emprego por via venosa não a elimina, uma vez que a concentração expirada do agente corresponde aos seus efeitos farmacodinâmicos sendo proporcional tanto à quantidade administrada como à profundidade anestésica que se deseja.

Quanto a prescindir de equipamentos sofisticados para sua vaporização e administração inalatória, estes seriam trocados por equivalentes para a infusão venosa.

Deve-se ainda esclarecer se existem repercussões metabólicas decorrentes do uso venoso desta emulsão lipídica, como acidemia e hipercolesterolemia, observadas com outros agentes venosos de formulação semelhante.

Assim, permanece a questão, que até o momento parece não ter sido respondida, sobre os benefícios desta proposta farmacotécnica.

Revista Brasileira de Anestesiologia

Vol. 54, N 5, Setembro - Outubro, 2004
A pesquisa, no entanto, não deve se pautar por benefícios óbvios e imediatos, pois no seu desenvolvimento, fatos novos podem ser observados e ganhos importantes obtidos.

Dra. Judymara Lauzi Gozzani, TSA

Editor-Chefe da RevistaBrasileira de Anestesiologia

\section{New Pharmacotechnique for Old Agents}

Experimental Anesthesiology may open new directions and propose solutions for Clinical Anesthesiology problems.

In 1995, Eger and MacLoad have studied intravenous administration of emulsified isoflurane in rats ${ }^{1}$. Major advantages reported by the authors were elimination of the anesthetic circuit of the ventilator and of lung functional residual capacity, allowing for faster anesthetic induction. At the end of the study, authors have concluded that the technique was feasible, and that anesthetic induction and maintenance were safe and reproducible. They have also suggested that other studies with larger animals would be important to determine toxicological, physico-chemical, pharmacokinetic and pharmacodynamic properties of this or of similar mixtures. In 1984 and 1999, one European and one American group have respectively studied pharmacokinetic and pharmacodynamic effects of halothane lipid emulsion in dogs, rats and swine. These studies have described single injection and infusion groups, isolated or combined, with pharmacological behavior similar to inhalational administration. No toxic effect has been observed but there has been a 12-fold increase in plasma triglycerides concentration in dogs ${ }^{2-4}$.

In this edition of the Brazilian Journal of Anesthesiology, a Brazilian group of investigators ${ }^{5}$ has presented an experimental model in swine to study some pharmacokinetic and pharmacodynamic characteristics of emulsified isoflurane. Results were similar to Eger and MacLoad's, with direct relationship between pharmacodynamic effects and isoflurane expired concentration.

The use in Brazil of inhalational induction of anesthesia is mainly in children, in whom it is sometimes difficult to obtain venous access. Inhalational anesthetic induction in this group of patients is in general fast due to their pulmonary function physiological characteristics. The possible advantage of fast intravenous induction is counteracted by its difficult access. Environmental contamination by inhalational anesthetics is not prevented by intravenous administration since agent's expired concentration corresponds to its pharmacodynamic effects being proportional both to dose administered and desired anesthetic depth. 
As to doing without sophisticated vaporization and inhalational administration equipment, these would be replaced by intravenous infusion equivalents.

It should also be determined whether there are metabolic repercussions of intravenous administration of this lipid emulsion, such as acidemia and hypercholesterolemia, observed with other intravenous agents with similar formulation.

So, the question about the benefits of this pharmacotechnical proposal still remains.

Research, however, should not be based on obvious and immediate benefits, because during development new facts may be observed and major gains may be obtained.

Judymara Lauzi Gozzani, TSA. M.D.

Editor-in-Chief, Brazilian Journal of Anesthesiology

\section{REFERÊNCIAS - REFERENCES}

01. Eger RP, MacLeod BA - Anaesthesia by intravenous emulsified isoflurane in mice. Can J Anaesth, 1995;42:836-837.

02. Johannesson G, Alm P, Biber B et al - Halothane dissolved in fat as an intravenous anaesthetic to rats. Acta Anaesthesiol Scand, 1984;28:381-384.

03. Biber B, Johannesson G, Lennander O et al - Intravenous infusion of halothane dissolved in fat. Haemodynamic effects in dogs. Acta Anaesthesiol Scand, 1984;28:385-389.

04 . Musser JB, Fontana JL, Mongan PD - The anesthetic and physiology effects of an intravenous administration of a halothane lipid emulsion (5\% vol/vol), Anesth Analg, 1999;88:671-674.

05. Mathias LAST, Piccinini Filho L, Rites JC et al - Isoflurano em emulsão lipídica por via venosa promove estabilidade cardiovascular respiratória em modelo experimental. Rev Bras Anestesiol, 2004;54:650-662. 